\title{
Maria Immacolata Spagna, Evoluzione e diffusione dell'arte in Francia (1855-1910) ed Emile Zola critico d'arte e romanziere
}

\section{Mario Richter}

\section{(2) OpenEdition \\ Journals}

Edizione digitale

URL: http://journals.openedition.org/studifrancesi/9636

DOI: $10.4000 /$ studifrancesi.9636

ISSN: 2421-5856

\section{Editore}

Rosenberg \& Sellier

\section{Edizione cartacea}

Data di pubblicazione: 1 décembre 2007

Paginazione: 689

ISSN: 0039-2944

\section{Notizia bibliografica digitale}

Mario Richter, «Maria Immacolata Spagna, Evoluzione e diffusione dell'arte in Francia (1855-1910) ed Emile Zola critico d'arte e romanziere», Studi Francesi [Online], 153 (LI | III) | 2007, online dal 30 novembre 2015, consultato il 11 janvier 2021. URL: http://journals.openedition.org/studifrancesi/9636 ; DOI: https://doi.org/10.4000/studifrancesi.9636

Questo documento è stato generato automaticamente il 11 janvier 2021.

\section{cc) $($ ) $\ominus$}

Studi Francesi è distribuita con Licenza Creative Commons Attribuzione - Non commerciale - Non opere derivate 4.0 Internazionale. 


\title{
Maria Immacolata Spagna, Evoluzione e diffusione dell' arte in Francia (1855-1910) ed Emile Zola critico d'arte e romanziere
}

\author{
Mario Richter
}

\section{NOTIZIA}

MARIA IMMACOLATA SPAGNA, Evoluzione e diffusione dell'arte in Francia (1855-1910) ed Emile Zola critico d'arte e romanziere, Lecce, Adriatica Editrice Salentina, 2005, pp. 224.

1 Alcuni interventi giornalistici e letterari di Zola sull'arte del suo tempo portano l'A. ad affermare che «con l'estetica impressionista Zola promuove e difende un nuovo sentire del gusto estetico più vivace e animato da colori e movimenti, ma soprattutto sostiene la ricchezza della varietà dei soggetti che dà spazio, nel quadro, alla rappresentazione della gente comune e della vita quotidiana» (p. 190).

2 Poiché l'impressionismo costituisce il fulcro di questo libro (che si vuole avvalere di un'appendice di 18 illustrazioni a colori, anche se questi risultano nella riproduzione gravemente alterati), stupisce l'assenza (anche in bibliografia) dei fondamentali scritti teorici di Jules Laforgue (se ne veda la raccolta nel volume curato da Mireille DotTin, J. Laforgue, Textes de critique d'art, Lille, Presses Universitaires de Lille, 1988), scritti che certamente avrebbero consentito all'A. di mettere a fuoco con maggiore precisione la natura del movimento impressionista. 